\title{
Eufemisme dan Disfemisme dalam Karangan Emha Ainun Nadjib: "Hidup Itu Harus Pintar Ngegas dan Ngerem"
}

\author{
Habib Rois \\ Universitas Sebelas Maret Surakarta \\ habibrois98@gmail.com
}

DOI: https://doi.org/10.32528/bb.v6i1.4031

First received: 03-01-2021

Final proof received: 25-02-2021

\begin{abstract}
ABSTRAK
Perubahan makna kata dengan penghalusan (eufemisme) dan pengasaran (disfemisme) terjadi dalam tataran kalimat yang dimarkahi oleh kata, frasa, dan klausa. Tujuan penelitian ini mendeskripsikan bentuk eufemisme dan disfemisme pada karangan Emha Ainun Nadjib (Cak Nun) dengan judul "Hidup Itu Harus Pintar Ngegas dan Ngerem" melalui analisis komponensial. Paradigma dalam penelitian menggunakan kualitatif dengan mengacu pada aksioma alamiah realitas, hubungan antara peneliti dengan yang diteliti, kemungkinan generalisasi, dan hubungan sebab akibat. Data dalam penelitian ini berupa kalimat dalam karangan Cak Nun yang termasuk dalam proses perubahan makna eufemisme dan disfemisme. Data diambil dari buku dengan judul "Hidup Itu Harus Pintar Ngegas dan Ngerem", sebuah tulisan yang memuat motivasi dan ajaran hidup berdasarkan syariat Islam. Proses analisis data dalam penelitian ini meliputi empat tahapan yaitu analisis domain, analisis taksonomi, analisis komponensial, dan analisis tema budaya. Hasil dalam penelitian ini memuat bentuk eufemisme dengan dua modus penggunaannya, yaitu perlindungan dan motivasi. Sedangkan disfemisme memiliki dua bentuk modus penggunaan yang meliputi penilaian negatif dan sindiran. Keempat modus tersebut kemudian dipadukan dengan padanan kata sesuai dengan konteks kalimat sehingga menimbulkan perbandingan berdasarkan komponen makna yang terkandung. Perbandingan komponen makna bertujuan untuk mengetahui tingkat perubahan makna yang merujuk pada penghalusan dan pengasaran. Terdapat satu kata tanpa membandingkan komponen makna dengan padanan katanya yaitu pada kata pramonyet. Istilah pramonyet digunakan sebagai bentuk pengasaran yang merujuk pada proses pengibaratan antara perlikau manusia dengan seekor monyet. Kata kunci: perubahan makna; eufemisme; disfemisme; komponen makna
\end{abstract}

\footnotetext{
ABSTRACT

Changes in the meaning of words with refinement (euphemism) and refinement (dysfemism) occur at the level of a sentence marked by words, phrases and clauses. The purpose of this research is to describe the forms of euphemisms and dysphemisms in the essay of Emha Ainun Nadjib (Cak
} 
Nun) with the title "Life Must Be Clever Ngegas and Ngerem" through a component analysis. The paradigm in research uses qualitative by referring to the natural axioms of reality, the relationship between the researcher and the one being studied, the possibility of generalization, and the causal relationship. The data in this study are in the form of sentences in Cak Nun's essay which are included in the process of changing the meaning of euphemisms and dysfemisms. The data is taken from a book entitled "Life Must Be Smart and Ngerem", an article that contains motivation and teachings of life based on Islamic law. The data analysis process in this study includes four stages, namely domain analysis, taxonomic analysis, component analysis, and cultural theme analysis. The results in this study contain a form of euphemism with two modes of use, namely protection and motivation. Meanwhile, dysphemism has two modes of use which include negative evaluation and satire. The four modes are then combined with the equivalent words in accordance with the context of the sentence, giving rise to comparisons based on the meaning components contained. Comparison of meaning components aims to determine the level of meaning change which refers to refinement and roughing. There is one word without comparing the meaning component with its equivalent, namely the word pramonyet. The term pramonyet is used as a form of curbing which refers to the process of comparing human needs with a monkey.

\section{Keywords: change of meaning; euphemism; dysfemism; meaning component}

\section{PENDAHULUAN}

Sebuah kata memiliki kontruksi makna yang berbeda-beda. Sebuah kata dalam bentuk dasar ketika digunakan dalam konteks yang berbeda, maka dapat menimbulkan makna yang berbeda pula. Kondisi mengenai sebuah makna kata, sangat bergantung pada struktur dan konteks yang melatarbelakanginya. Salah satu model perubahan makna sebuah kata, frasa atau kalimat adalah eufemisme dan disfemisme. Eufemisme berkaitan dengan penghalusan makna, sedangkan disfemisme berkaitan dengan pengasaran makna. Perubahan makna dapat pula berupa perluasan makna dan penyempitan makna (Heryana, 2019).

Berubahnya sebuah makna eufemisme dan disfemisme dalam tataran kata, frasa, klausa maupun kalimat dipengaruhi oleh adanya modus dan konteks penggunaannya. Penghalusan dan pengasaran dalam Bahasa Indonesia sangat umum terjadi, khususnya dalam wacana lisan maupun tulis. Salah satu bentuk wacana tulis yang berkaitan dengan proses eufemisme dan disfemisme adalah pada buku Emha Ainun Nadjib dengan judul "Hidup itu Harus Pintar Ngegas \& Ngerem". Sebuah buku yang dibuat dengan memuat motivasi dan ajaran hidup sesuai dengan syariat agama islam.

Karangan Emha Ainun Nadjib atau lebih akrab disapa dengan Cak Nun ini ditulis dengan bahasa-bahasa kias yang dapat memengaruhi pola pikir pembaca. Isi dari karangan Cak Nun berisi motivasi, ajaran hidup, dan bagaimana islam menghadapi sebuah permasalahan dari segi politik, budaya, sains, kearifan lokal, tafsir, dsb. Buku ini memuat tema-tema yang ditulis dengan bahasa kias seperti pada bab Kabar Langit dengan 
Bahasa Bumi, Hidup itu Harus Pintar Ngegas dan Ngerem, dan Tafsir tematis duniaakhirat. Banyak ungkapan-ungkapan yang ditulis dengan menggunakan bahasa yang bervariasi, mulai dari istilah dalam dunia politik, budaya, ilmu tafsir, bahasa Arab, dsb. Kevariasian ini membentuk sebuah kontruksi bahasa yang dapat merubah sebuah makna tertentu yang berkaitan dengan eufemisme dan disfemisme.

Salah satu bentuk eufemisme dalam karangan Cak Nun ini yaitu pada kalimat "Tidak usah. Aku sudah mendoakan agar orang-orang yang menganiayaku bisa mendapatkan hidayah dan seluruh keturunannya nanti jadi pemimpin umat islam". Ungkapan tersebut merupakan bentuk penghalusan dari permasalah yang membuat penulis (Cak Nun) merasa ingin membalas atas kesalahan tersebut. Munculnya kata menganiayaku merupakan representasi dari adanya sebuah permasalahan yang menimbulkan rasa balas dendam. Namun, sebelum kata tersebut penulis sudah memberikan bentuk penghalusan dengan klausa "aku sudah mendoakan". Ungkapan seperti yang dicontohkan tersebut merupakan representasi penghalusan dalam tataran kalimat yang memuat kata dan klausa. Namun ada bentuk penghalusan yang berstruktur kalimat penuh, artinya proses penghalusan atau pengasarannya berkaitan dengan seluruh maksud dari kalimat tertentu.

Penelitian Kurniawati (2011) menguraikan bentuk eufemisme dan disfemisme dalam spiegel online. Proses perubahan eufemisme dan disfemisme diproyeksikan berdasarkan latar belakangnya, sehingga makna penghalusan dan pengasarannya diklasifikasikan berdasarkan modus latar belakangnya. Selain itu, Heryana (2019) mengembangkan penelitian eufemisme dan disfemisme pada bentuk inovasi formal berupa pembentukan kata, modifikasi fonem, dan kata pinjaman. Selanjutnya, proses eufemisme ditujukan untuk sebuah perlindungan, penghalusan ucapan, provokasi, penyemangat, menutupi kecuarangan, dan berdiplomasi. Sedangkan disfemisme sebagai penggambaran negatif tentang seseorang atau sesuatu hal, menunjukkan sesuatu yang bernilai rendah, melebihkan sesuatu hal, menunjukkan rasa tidak hormat.

Eufemisme dan disfemisme merujuk pada perubahan yang sangat dipengaruhi oleh konteks penggunaan (Jayanti, et al, 2019). Konteks yang dimaksudkan merujuk pada tujuan atau maksud dari kalimat tertentu. Selanjutnya, proses perubahan makna yang berbentuk penghalusan dan pengasaran dalam hal ini hanya diklasifikasikan ke dalam bentuk kelas kata. Eufemisme dikelompokkan dan diuraikan berdasarkan kelas kata yang melatarbelakanginya, begitu juga pada tataran disfemisme. Sehingga hasil yang dimunculkan merujuk pada sebuah maksud dari kalimat yang mengalami penghalusan atau pengasaran tersebut.

Berdasarkan review di atas, muncul gap yang berkaitan dengan proses eufemisme dan disfemisme yang diuraikan dengan menggunakan komponen makna. Bentuk penelitian di atas memfokuskan pada proses eufemisme dan disfemisme berdasarkan latar belakang kalimat, bentuk inovasi formal berupa pembentukan kata, dan klasifikasi berdasarkan kelas kata. Analisis pada penelitian tersebut belum menguraikan bentukbentuk perubahan yang didasarkan pada komponen yang melandasi adanya perubahan. Berkaitan dengan gap tersebut, maka tujuan dalam penelitian ini adalah menganalisis dan mendeskripsikan bentuk eufemisme dan disfemisme pada karangan Emha Ainun Nadjib 
dengan judul "Hidup Itu Harus Pintar Ngegas dan Ngerem" melalui analisis komponensial.

\section{METODE PENELITIAN}

Penelitian ini merupakan penelitian kualitatif yang menguraikan kasus-kasus perubahan makna eufemisme dan disfemisme berdasarkan analisis komponensial. Dasar pemilihan paradigma kualitatif ini mengacu pada aksioma naturalis yang dikemukakan oleh Lincoln \& Guba (1985). Aksioma naturalis meliputi sifat alamiah realitas, hubungan antara peneliti dengan yang diteliti, kemungkinan generalisasi, dan hubungan sebab akibat (Lincoln \& Guba dalam Santosa, 2017). Aksioma sifat alamiah realitas didasarkan pada perubahan makna terjadi pada wacana tulis dalam karangan Emha Ainun Nadjib. Kasus sosial-bahasa tersebut memiliki hubungan interaktif yang tidak dapat dipisahkan oleh peneliti. Selain itu, aksioma generalisasi dalam konsep penelitian ini mengarah pada konteks kalimat yang mengalami perubahan makna. Selanjutnya, hubungan sebab akibat dalam kasus sosial bahasa etiket linguistik merujuk pada proses perubahan yang diakibatkan oleh adanya penyesuaian konteks.

Data dalam penelitian ini berupa kalimat yang memuat bentuk perubahan makna eufemisme dan disfemisme. Lebih jelas, kalimat yang dimaksud secara struktural memiliki satuan kata, frasa, atau klausa yang menyatu sehingga menimbulkan adanya perubahan makna kata. Kalimat tersebut bersumber dari karangan Emha Ainun Nadjib yang berjudul "Hidup Itu Harus Pintar Ngegas dan Ngerem". Sebuah buku yang bergenre nonfiksi karena berisi motivasi dan ajaran hidup berdasarkan syariat Islam.

Data yang telah diambil kemudian dianalisis dengan menggunakan model analisis Spradely \& Guba (dalam Santosa, 2017). Analisis data tersebut meliputi analisis domain, taksonomi, komponensial, dan analisis budaya. Bentuk analisis domain dalam hal ini dibedakan berdasarkan komponen makna yang terkandung dalam setiap kata eufemisme dan disfemisme. Selanjutnya, Bentuk analisis taksonomi dalam penelitian ini didasarkan pada modus eufemisme yang berupa perlindungan dan motivasi, serta modus disfemisme yang berupa sindiran dan penilaian negatif. Kedua bentuk analisis tersebut digabungkan sehingga menjadi analisis komponensial. Berikut merupakan tabel analisis komponensial yang digunakan untuk menganalisis data secara keseluruhan.

\section{Tabel 1: Analisis Komponensial Data Penelitian}

\begin{tabular}{|c|c|c|c|c|}
\hline \multirow{2}{*}{ Bentuk } & \multicolumn{2}{|c|}{ Eufemisme } & \multicolumn{2}{|c|}{ Disfemisme } \\
\hline & Perlindungan & Motivasi & Sindiran & Penilaian negatif \\
\hline Kata & - & - & Dis-5.119 & - \\
\hline \multirow[t]{2}{*}{ Frasa } & Eu-2.13 & Eu-4.127 & Dis-3.77 & Dis-1.5 \\
\hline & - & - & - & Dis-2.23 \\
\hline Klausa & Eu-1.13 & Eu-3.113 & Dis-4.89 & - \\
\hline
\end{tabular}

Setelah melalui ketiga analisis di atas, selanjutnya adalah analisis tema budaya. Bentuk analisis tema budaya dalam paradigma kualitatif bukan mengarah pada bentuk kebudayaan yang bersifat etnik, akan tetapi merupakan proyeksi grounded teori dengan hasil penelitian (Santosa, 2017). Lebih lenjut, dalam analisis budaya ini bentuk 
eufemisme dan difemisme dipadukan dengan penelitian sebelumnya dan juga teori yang ada dalam tataran semantik.

\section{PEMBAHASAN}

Analisis terkait bentuk eufemisme dan disfemisme dalam karangan Emha Ainun Nadjib dengan judul "Hidup Itu Harus Pintar Ngegas dan Ngerem" diklasifikasikan berdasarkan modus eufemisme yang meliputi perlindungan dan motivasi serta modus disfemisme yang meliputi penilaian negatif dan sindiran.

\section{Eufemisme Modus Perlindungan}

Proses perubahan kata pada eufemisme terdapat pada data dengan kode (Eu-1.13) dan (Eu-1.13). Penghalusan makna dalam hal ini bertujuan memberikan sebuah perlindungan terhadap suatu unsur dengan memberikan diksi yang lebih sopan dan berterima. Berikut merupakan uraian eufemisme dengan modus perlindungan.

(1) Tidak usah. Aku sudah mendoakan agar orang-orang yang menganiayaku bisa mendapatkan hidayah dan seluruh keturunannya nanti jadi pemimpin umat islam (Eu-1.13)

Pada data 1 dengan kode (Eu-1.13) terdapat ungkapan yang merupakan proses penghalusan dari bentuk awalnya. Kata mendoakan umumnya digunakan dalam sebuah pernyataan untuk hal kebaikan. Selain itu penggunaan kata mendoakan umumnya dilengkapi dengan kata atau frasa yang menjadi satu dalam konteks hal positif. Namun pada data (1) bersifat sebaliknya, kata mendoakan dipasangkan dengan kata menganiaya. Terjadi kontras makna yang cukup terlihat antar dua kata ini. Terjadi proses penghalusan akibat adanya sebuah kesalahan orang lain kepada Cak Nun, namun secara holistik Cak Nun memberikan umpan sebaliknya dengan mendoakan atas kesalahan dari orang yang telah menganiaya. sehingga data (1) di atas termasuk proses penghalusan dalam bentuk klausa, yaitu Aku sudah mendoakan. Kata mendoakan secara leksikal berkaitan dengan permohonan kepada Tuhan Yang Maha Esa. Lebih jelas, penggunaan kata mendoakan merupakan pemilihan yang paling cocok dan mempunyai sifat kehalusan yang lebih dibandingkan dengan padanan katanya yang berupa kata memohonkan, meniatkan, dan merestui. Berikut ini merupakan bentuk komponen makna dalam padanan kata mendoakan.

Tabel 2: Komponen Makna dalam Padanan Kata Mendoakan

\begin{tabular}{lcccc}
\hline \multirow{2}{*}{ Kata } & \multicolumn{5}{c}{ Komponen } \\
\cline { 2 - 5 } & $\begin{array}{c}\text { Membaca } \\
\text { pujian }\end{array}$ & $\begin{array}{c}\text { Memuja } \\
\text { Tuhan }\end{array}$ & $\begin{array}{c}\text { Hubungan } \\
\text { manusia }\end{array}$ & $\begin{array}{c}\text { Hubungan } \\
\text { dengan Tuhan }\end{array}$ \\
\hline Mendoakan & + & + & - & + \\
\hline Memohonkan & - & - & + & - \\
\hline Meniatkan & + & + & + & + \\
\hline Merestui & - & - & + & - \\
\hline
\end{tabular}

Berdasarkan perbandingan komponen makna di atas, terdapat perbedaan pola yang merujuk pada tingkat kehalusan pada eufemisme. Kata mendoakan memiliki komponen yang berkaitan dengan urusan antara manusia kepada Tuhan. Selain itu, adanya komponen membaca pujian atau melafalkan doa menunjukkan bahwa kata 
mendoakan dipandang lebih halus jika dipadukan dengan kata menganiaya dalam kalimat Aku sudah mendoakan agar orang-orang yang menganiayaku.

(2) Merapi tidak meletus. Tapi, merapi sedang punya hajat (Eu-1.13)

Bentuk eufemisme pada data (2) dengan kode (Eu-1.13) ditandai dengan pemarkah pada kata hajat. Frasa tidak meletus berperan sebagai titik awal penghalusan munculnya kata hajat. Lebih jelas, penggunaan kata hajat bertujuan untuk penghalusan makna. Secara leksikal kalimat (2) dapat diproyeksikan bahwa merapi sedang meletus. Namun, Cak Nun memberikan penambahan ungkapan merapi sedang punya hajat, sehingga data (2) terlihat lebih halus. Pemilihan diksi ini secara leksikal memiliki komponen yang lebih halus jika dibandingkan dengan padanan katanya. Berikut merupakan bentuk komponen makna pada kata hajat sebagai bentuk perbandingan.

Tabel 3: Komponen Makna dalam Padanan Kata Hajat

\begin{tabular}{lcccc}
\hline \multirow{2}{*}{ Kata } & \multicolumn{5}{c}{ Komponen } \\
\cline { 2 - 5 } & Keperluan & Keselamatan & $\begin{array}{c}\text { Serangkaian } \\
\text { kegiatan }\end{array}$ & Nikmat (n) \\
\hline Hajat & + & + & + & + \\
\hline Maksud & + & - & - & - \\
\hline Keinginan & + & - & - & - \\
\hline Acara & + & - & + & - \\
\hline
\end{tabular}

Berdasarkan tabel 3, terlihat bahwa kata hajat memiliki kontruksi yang berkaitan dengan sebuah kegiatan yang bertujuan untuk mencari nikmat. Berkaitan dengan gunung meletus, umumnya dapat diungkapkan dengan bencana alam. Tetapi Cak Nun memberikan gambaran lain, yaitu dengan memilih kata hajat agar unsur penghalusannya berkaitan dengan perlindungan. Sekaligus sebuah ajakan bahwa gunung meletus jangan dipandang sebagai bencana alam belaka, akan tetapi melalui gunung meletus kita sebagai hamba-Nya harus sering mensyukuri nikmat-Nya agar mencapai kesejahteraan hidup dan dijauhkan dari bencana alam yang menimpa.

Bentuk eufemisme dengan modus melindungi ini terjadi dengan pemarkah sebuah ekspresi penghindaran. Bentuk tersebut selaras dengan penyataan Burridge (2012) bahwa eufemisme ditandai dengan bahasa penghindaran dan ekspresi mengelak. Penghindaran dalam hal ini diartikan sebagai sebuah bentuk penghalusan dari bentuk aslinya. Komponen makna yang melekat pada pemilihan kata merepresentasikan bentuk yang akan membedakan modus setiap jenis eufemisme. Di sisi lain Melcuk (2012) memberikan penegasan bahwa sebuah kata dapat bermakna jika direpresentasikan melalui bentuk tulisan atau teks secara langsung, tanpa memasukkan fungsi ekspresi dari sebuah kalimat. Kedua pernyataan tersebut pada dasarnya saling berpengaruh. Bentuk kolaborasi antar dua pernyataan tersebut dapat diwujudkan dalam contoh kalimat "Tidak usah. Aku sudah mendoakan agar orang-orang yang menganiayaku bisa mendapatkan hidayah dan seluruh keturunannya nanti jadi pemimpin umat islam”. Munculnya kata mendoakan memberikan pengalihan ekspresi yang berbanding terbalik dari kata menganiayaku. Secara struktural, kata tersebut saling berkolaborasi secara tertulis, namun secara ekspresif juga memberikan gambaran mengenai bentuk pengalihan. Berdasarkan 
pandangan di atas yang disertai dengan temuan penelitian, maka bentuk eufemisme pada dasarnya mengarah pada makna kata yang dapat diwujudkan secara tertulis maupun lisan. Selain itu dapat diuraikan dengan memilih padanan kata yang berhubungan untuk mencari komponen makna yang menjadikan ciri eufemisme dengan modus perlindungan.

\section{Eufemisme Modus Motivasi}

Eufemisme dengan modus motivasi berisi penghalusan kata yang sekaligus memberikan arahan kepada pembaca untuk melakukan atau tidak melakukan sesuatu yang diisyaratkan pada kalimat tertentu. Bentuk eufemisme modus motivasi terdapat pada data dengan kode (Eu-3.113) dan (Eu-4.127). Berikut merupakan deskripsi terkait analisis eufemisme pada modus motivasi.

(3) Jangan benci setan. Cari manfaatnya, yaitu supaya kamu mempertahankan iman. (Eu-3.113)

Data (3) mengandung bentuk kasar yang dihaluskan dengan memberikan ungkapan pada kata selanjutnya. Klausa Jangan benci setan secara leksikal merupakan pernyataan dengan memberikan negasi tidak yang merujuk pada sifat setan. Selanjutnya klausa tersebut ditambahkan dengan bentuk klausa lain yaitu Cari manfaatnya. Terdapat unsur motivasi yang terletak pada klausa lanjutan, sekaligus berperan sebagai bentuk penghalusan dari klausa pertama. Pemilihan kata manfaat memiliki bentuk padanan yang melandasi adanya penghalusan yaitu kata berfungsi, berguna, dan berfaedah.

Tabel 4: Komponen Makna dalam Padanan Kata Bermanfaat

\begin{tabular}{lcccc}
\hline \multirow{2}{*}{ Kata } & \multicolumn{5}{c}{ Komponen } \\
\cline { 2 - 5 } & Kebaikan & Keuntungan & Maslahat & Nikmat $(\boldsymbol{n})$ \\
\hline Bermanfaat & + & + & + & + \\
\hline Berfungsi & + & + & - & - \\
\hline Berguna & + & - & - & - \\
\hline Berfaedah & + & + & + & + \\
\hline
\end{tabular}

Berdasarkan bentuk komponen makna dalam padanan kata bermanfaat, terlihat bahwa kata bermanfaat dan berfaedah memiliki bentuk komponen yang sama. Kedua kata ini memiliki kepaduan yang merujuk pada maslahat untuk mendapatkan sebuah nikmat-Nya. Selanjutnya, kata bermanfaat dipilih sebagai bentuk penghalusan dari pernyataan bahwa tidak perlu membenci setan, akan tetapi mencari manfaatnya untuk mempertahankan iman.

(4) Namun, kendati pergantian kepemimpinan Indonesia tidak penting, bukan berarti hal itu tidak harus diperhatikan. Tetap harus diperhatikan, tapi ada takaran yang tepat untuk hidupmu semua. (Eu-4.127)

Kalimat (4) terjadi proses eufemisme dengan pemarkah pada klausa bentuk tapi ada takaran yang tepat untuk hidupmu semua. Kalimat tersebut secara leksikal merupakan proyeksi dari ungkapan tingkatan setiap seseorang berbeda-beda. Munculnya kata takaran merupakan proyeksi dari kata tingkatan, sehingga pemilihan kata ini bertujuan sebagai proses penghalusan makna kata aslinya. Sebagai acuan, kata takaran 
dibandingkan dengan padanan katanya yang meliputi kata tingkatan, dan kadar. Berikut merupakan bentuk komponen makna dalam padanan kata takaran.

Tabel 5: Komponen Makna dalam Padanan Kata Takaran

\begin{tabular}{lccc}
\hline \multirow{2}{*}{ Kata } & \multicolumn{3}{c}{ Komponen } \\
\cline { 2 - 4 } & Martabat & Kandungan & Ukuran \\
\hline Takaran & - & - & + \\
\hline Tingkatan & + & - & + \\
\hline Kadar & - & + & - \\
\hline
\end{tabular}

Padanan kata berdasarkan tabel komponen makna di atas menggambarkan distribusi yang cukup beragam. Kata takaran jika dikaitkan dengan kalimat (4) memiliki bentuk penghalusan. Namun, padanan kata tingkatan lebih merepresentasikan sebuah martabat yang berkaitan dengan konteks kalimat (4). Istilah takaran dalam kalimat (4) diproyeksikan sebagai sebuah tingkatan status sosial seseorang. Jika dilihat dari komponen maknanya, pemilihan kata takaran sudah mengandung unsur penghalusan dari pernyataan sebelumnya, namun jika pemilihan katanya menjadi tingkatan maka secara leksikal makna dalam kalimat (4) lebih tergambar jelas dan sesuai dengan maksud kalimat.

Eufemisme dengan modus motivasi bertujuan untuk memberikan penguatan atas penyataan yang disampaikan dalam sebuah kalimat. Heryana (2019) menguraikan secara umum bahwa eufemisme berfungsi sebagai sebuah alat penghalusan bahasa. Penghalusan yang terjadi merupakan bentuk pengalihan dari kata sebenernya dengan tujuan untuk memberikan kesan positif dalam sebuah kalimat. Seiring dengan pernyataan tersebut, terdapat satu bentuk penghalusan yang berkaitan dengan pemberian motivasi kepada pembaca maupun pendengar. Kalimat pada nomor 3 dan 4 merupakan bentuk penghalusan yang sekaligus memberikan motivasi secara tidak langsung. Sehingga selain penghalusan yang bersifat melindungi, eufemisme mempunyai peran sebagai bentuk penghalusan yang sekaligus memberikan motivasi.

\section{Disfemisme Modus Penilaian Negatif}

Disfemisme atau pengasaran makna dalam modus ini merujuk pada sebuah penilaian terhadap sesuatu hal yang dirasa kurang bagus. Biasanya modus penilaian negatif dalam disfemisme dintandai dengan adanya kata negasi seperti tidak dan lain sebagainya. Bentuk disfemisme penilaian negatif dalam karangan Cak Nun "Hidup itu Harus Pintar Ngegas dan Ngerem” terdapat pada data Dis-1.5 dan Dis-2.23.

\section{(5) Sekolah tidak menjamin orang belajar dan berbuat baik. (Dis-1.5)}

Data (5) dengan kode Dis-1.5 terjadi pengasaran makna yang dimarkahi oleh frasa negasi tidak menjamin. Secara konteks, sebuah lembaga sekolah memiliki tujuan dan luaran yang terstruktur terutama dalam kegiatan belajar dan memperbaiki sebuah sikap. Pernyataan tersebut muncul dikarenakan pandangan Cak Nun terhadap sebuah sekolah berada pada perspektif proses learning by doing. Menurut Cak Nun dalam karangannya, sekolah memang tempatnya orang mencari ilmu dan belajar. Namun orang belajar dan orang berpura-pura belajar beda tipis. Seseorang dikatakan belajar, ketika ia mampu 
menghadapi sebuah masalah tanpa meninggalkannya dengan cara menangkap segala apa yang dikatakan oleh seorang guru. Sedangkan seseorang yang berpura-pura belajar adalah ketika ia datang ke sekolah dengan berseragam namun kehadirannya hanya untuk berkumpul, menghabiskan uang orang tua, bermain, tanpa memahami sebuah permasalahan dalam kehidupan sosial yang diajarkan oleh seorang guru.

Pengasaran di atas, mempunyai makna yang cukup dalam dengan perspektif realitas menurut Cak Nun. Keadaan sebenarnya menurut Cak Nun memang demikian, banyak anak yang ke sekolah untuk belajar tapi nyatanya ia melah merasa cerdas sehingga tidak memahami sejatinya hidup secara vertikal dan horizontal. Frasa tidak menjamin merujuk pada keadaan sebenarnya, banyak siswa yang ketika lulus dari sekolahan, mereka bercita-cita tinggi tanpa diimbangi sebuah usaha dan doa. Akhirnya seseorang tidak memahami yang namanya hidup yang berhubungan dengan urusan vertikal. Secara leksikal kata menjamin memiliki komponen makna tertentu yang menimbulkan perbedaan tingkatan disfemisme. Padanan kata menjamin yaitu menyelamatkan, mengamankan, dan menanggung. Berikut merupakan perbandingan komponen makna pada padanan kata menjamin.

Tabel 6. Komponen Makna dalam Padanan Kata Menjamin

\begin{tabular}{lcccc}
\hline \multirow{2}{*}{ Kata } & \multicolumn{5}{c}{ Komponen } \\
\cline { 2 - 5 } & Pasti & Keselamatan & Tanggungan & Bahaya \\
\hline Menjamin & + & + & + & - \\
\hline Menyelamatkan & + & + & - & + \\
\hline Mengamankan & - & + & - & + \\
\hline Menanggung & + & - & + & - \\
\hline
\end{tabular}

Berdasarkan tabel 6, komponen makna pada kata menjamin mengarah pada sebuah kepastian, keselamatan, tanggungan. Pemilihan kata menjamin memiliki komponen yang hampir penuh, sehingga bentuk pengasaran pada frasa tidak menjamin merepresentasikan sebuah tanggungan yang tidak merujuk pada hal yang berbahaya. Sekolah pada dasarnya merupakan lembaga di mana seseorang mencari ilmu, belajar, dan memperbaiki sikap. Namun terjadi pengasaran dengan memberikan negasi tidak. Namun, pengasaran ini didasarkan pada perspektif proses belajarnya.

(6) Banyak orang pintar di sekolah tapi tidak pintar hidup. Bekerja tidak bisa, dagang tidak bisa, jadi orang yang dipercaya orang lain tidak bisa, akhirnya nyaleg. (Dis-2.23).

Bentuk disfemisme dengan modus penilaian negatif terjadi pada data (6) dengan pemarkah tidak pintar hidup. Sesuatu yang bersifat pintar secara akumulatif tidak dapat diukur, terutama dalam menjalani hidup. Pemarkah tidak pintar hidup merupakan bentuk pengasaran dari kata kedewasaan. Makna tersirat pada data (6) mengarah pada sebuah perilau kedewasaan seseorang dalam menjalani hidup, namun Cak Nun menggunakan frasa tidak pintar hidup sehingga mengalami proses perubahan makna pada bentuk disfemisme. Proses pengasaran pada kata hidup ini secara komponensial memilikki struktur yang beragam dengan padanan katanya. Padanan kata hidup jika dikaitkan 
dengan data (6) yaitu muncul, tumbuh, dan berkembang, untuk memahami tingkat pengasarannya berikut merupakan tabel komponen makna dalam padanan kata hidup.

Tabel 7: Komponen Makna dalam Padanan Kata Hidup

\begin{tabular}{lcccc}
\hline \multirow{2}{*}{ Kata } & \multicolumn{4}{c}{ Komponen } \\
\cline { 2 - 5 } & Aktivitas & Perubahan & Menuju baik & Berjiwa \\
\hline Hidup & + & + & + & + \\
\hline Muncul & + & + & - & - \\
\hline Tumbuh & + & + & - & + \\
\hline Berkembang & + & + & + & - \\
\hline
\end{tabular}

Komponen makna yang dimiliki kata hidup mengarah pada bentuk aktivitas, yang mengalami sebuah perubahan menuju baik dan berjiwa. Pemilihan kata hidup dalam konteks kalimat (6) memiliki peran yang cukup memengaruhi proses pemaknaannya. Kata hidup memiliki bentuk komponen lebih lengkap jika dibandingkan dengan kata berkembang, sehingga memiliki makna leksikal yang lebih lengkap. Namun terjadi pengasaran dengan penambahan negasi tidak + kata pintar.

Bentuk disfemisme pada terjadi pada kata tertentu yang terdapat dalam satuan kalimat luas. Ritos \& Daud (2020) menyatakan bahwa sebuah bentuk disfemisme tidak selalu berkaitan dengan pengasaran yang dapat diterima secara akal dan hati lawan tutur. Terdapat titik acuan dalam menentukan disfemisme yang dikaitkan dengan kebudayaan suatu kelompok. Titik acuan tersebut meliputi rangka rujuk silang dan analisis relevan. Kedua konsep ini memberikan gambaran bahwa disfemisme akan berbeda persepsi jika dilakukan pada komunitas yang berbeda budaya dan kepercayaan. Namun pada penelitian ini, disfemisme diwujudkan dalam bentuk bahasa Indonesia yang secara umum memiliki satuan kebudayaan yang universal. Artinya, tidak condong pada kelompok tertentu, akan tetapi secara struktural bahasa indonesia dan konsep meaning of text, bentuk disfemisme diwujudkan dengan perubahan pernyataan yang bersifat pengasaran pada tulisan maupun tuturan tertentu. Maka berdasarkan temuan Ritos \& Daud (2020) serta hasil dalam penelitian ini, konsep disfemisme dapat berbeda persepsi pada suatu kelompok kecil dengan bahasa tertentu yang bukan merupakan lingua franca.

\section{Disfemisme Sindiran}

Pengsaran dengan modus sindiran merupakan proses perubahan makna yang terjadi dengan tujuan menyindir seseorang pada konteks tertentu. Bentuk disfemisme dalam modus sindiran terdapat pada data dengan kode Dis-3.77, Dis-4.89, dan Dis-5.119. Berikut merupakan uraian ketiga bentuk tersebut dan analisis komponensial setiap kata yang berperan sebagai permarkah.

(7) Seharusnya, negara dan pemerintah itu punya kewajiban menjamin hidup warga negaranya. Tapi, kenyatannya, mereka tidak bisa menjamin, sehingga banyak orang lari ke luar negeri. (Dis-3.77) 
Data (7) dengan kode Dis-3.77 terjadi proses perubahan disfemisme dengan pemarkah frasa tidak bisa menjamin. Terdapat penggunaan kata negasi tidak yang merujuk pada bentuk negatif. Bentuk klausa mereka tidak bisa menjamin merupakan pengasaran dari ungkapan belum mampu menciptakan lapangan pekerjaan yang sesuai. Menjamin yang dimaksudkan dalam kalimat (7) merujuk pada keadaan ekonomi masyarakat Indonesia yang masih banyak mengalami keterbatasan. Sehingga banyak WNI yang ke luar negeri untuk mencari kesejahteraan hidup. Pengasaran ini sekaligus mempunyai modus menyindir bentuk kepemerintahan saat itu, di mana alokasi tenaga kerja masih belum merata dan terbatasnya lapangan pekerjaan. Komponen makna kata menjamin dalam hal ini memiliki padanan dengan kalimat (5) kode Dis-1.5.

(8) Cerdik-pandai kok ditagih. Mereka itu sudah tidak punya perkerjaan. Mereka hanya sekolah, lalu menganggur. Kok malah kamu tagih, seharusnya yang ditagih adalah DPR, eksekutif, termasuk yudikatif. (Dis-4.89

Bentuk disfemisme selanjutnya terdapat pada kalimat (8) dengan pemarkah pengasaran pada klausa "kok,malah kamu tagih". Lebih khusus, terdapat penggunaan kata tagih yang direpresentasikan sebagai sebuah tanggunngan. Klausa kok malah kamu tagih merupakan bentuk pengasaran dari ungkapan meminta uang kepada rakyat kecil. Penggunaan kata tagih menggambarkan bentuk pemaksaan untuk melengkapi, membayar, dan memberikan tanggungan yang dialami. Selanjutnya, tingkat pengasaran pada klausa tersebut dibandingkan dengan padanan kata tagih. Padanan tersebut yaitu kata tuntut, minta, dan gugat, berikut merupakan komponen makna keempat kata tersebut.

Tabel 8: Komponen Makna dalam Padanan Kata Tagih

\begin{tabular}{lcccc}
\hline \multirow{2}{*}{ Kata } & \multicolumn{5}{c}{ Komponen } \\
\cline { 2 - 5 } & Terdesak & Tanggungan & Perkara & Hutang \\
\hline Tagih & + & + & - & + \\
\hline Tuntut & + & + & + & - \\
\hline Minta & - & + & - & + \\
\hline Gugat & + & - & + & - \\
\hline
\end{tabular}

Berdasarkan tabel 8 di atas, terdapat perbedaan penggunaan kata tagih, tuntut, minta, dan gugat. Kata tagih merujuk pada sesuatu hal yang bersifat mendesak, adanya tanggungan, dan hutang. Jika dikaitkan dengan klausa kok malah kamu tagih yang merupakan bentuk pengasaran dari ungkapan meminta uang kepada rakyat kecil, maka kata gugat mengarah pada konteks tagihan hutang. Kata tagih dalam konteks ini setara dengan kata minta, namun kata tagih memiliki bentuk yang lebih kasar dengan penanda sebuah hutang. Lain halnya dengan kata tuntut dan gugat, keduanya digunakan pada sebuah konteks yang berkaitan dengan perkara tertentu.

(9) Sekarang banyak manusia pramonyet. Monyet tidak melakukan money laundry. Monyet sebenarnya hanya menyimpan makanan di rumahnya. Tapi, sekarang 
disimpan di mana-mana. Itu berarti, sekarang banyak manusia pramonyet. (Dis5.119)

Bentuk disfemisme terakhir terdapat pada kalimat (9) dengan kode Dis-5.119 ditandai dengan pemarkah kata pramonyet. Istilah ini merupakan sebuah peranggapan yang bertujuan untuk menyindir oknum pemerintah. Pramonyet dalam hal ini merujuk pada perilaku monyet yang suka menyimpan makanan di sarangnya dan menyediakan makanan-makanan di berbagai tempat. Hal ini diibaratkan dengan seorang koruptor yang suka menyimpan uang di rumah dan tempat lainnya guna untuk meningkatkan kepemilikian pribadi. Kata pramonyet merupakan bentuk pengasaran dari istilah koruptor. Secara leksikal kata koruptor ini memiliki makna orang yang melakukan korupsi, orang yang menyelewengkan (menggelapkan) uang negara. Bentuk penggelapan yang dilakukan oleh para koruptor yaitu dengan menyimpan berbagai harta di dalam rumah dan pada tempat atau instansi-instansi tertentu. Perilaku tersebut diibaratkan dengan seekor monyet yang memiliki sifat sama. Sehingga kata pramonyet merupakan sebuah pengasaran sekaligus sindiran. Tanpa menggunakan analisis komponensial (komponen makna), kata pramonyet sudah memiliki proyeksi makna yang jelas yaitu permisalan perilaku manusia yang disamakan dengan seekor monyet.

Disfemisme merujuk pada pengasaran sebuah kata yang dapat menimbulkan sifat sindiran. Jayanti, et al (2019) menguraikan disfemisme berdasarkan kategori kata yang menjadi pemarkah. Namun, dalam penelitian ini kategori pada pemarkah tertentu bukan menjadi acuan utama, melainkan lebih fokus pada modus dari adanya pengasaran sebuah kalimat. Secara leksikal, kategori pemarkah bertujuan untuk menentukan distribusi kata pada bentuk eufemisme dan disfemisme. Namun, secara konseptual dan kontekstual perlu adanya komponen yang menghubungkan perpaduan makna antara padanan kata yang menjadi pemarkah dalam kalimat disfemisme. Hal tersebut merepresentasikan bahwa secara modus disfemisme, terdapat sifat penilaian negatif dan sindiran dalam bentuk perubahannya.

\section{Tingkat Perubahan Eufemisme dan Disfemisme}

Proses analisis komponensial dengan membandingkan komponen makna setiap padanan katanya bertujuan untuk mencari tingkat perubahan penghalusan dan pengasaran. Kurniawati (2011) dan Jayanti, et al (2019) menguraikan proses perubahan kata dilihat dari latar belakang dan bentuk kelas kata yang berperan sebagai pemarkah. Kedua proses tersebut memberikan proyeksi pada peranan pemarkah kata pada setiap proses efufemisme dan disfemisme. Namun, lebih jelas konsep tersebut belum mampu menguraikan seberapa halus dan seberapa kasar proses pemilihan katanya. Berdasarkan hal tersebut, perlu adanya analisis komponensial dengan membandingkan komponen makna kata yang sepadan. Selain itu, konsep komponen makna harus disesuaikan dengan konteks kalimat dengan tujuan agar mengetahui letak perbedaan setiap kata. 


\section{SIMPULAN}

Proses perubahan kata dalam eufemisme dan disfemisme sangat dipengaruhi oleh konteks penggunaannya. Makna yang timbul dari kedua proses tersebut secara lebih rinci dapat diproyeksikan dengan menggunakan analisis komponensial pada padanan kata yang menjadi pemarkah. Berdasarkan uraian di atas karangan Emha Ainun Nadjib dengan judul "Hidup Itu Harus Pintar Ngegas dan Ngerem" memiliki bentuk eufemisme dengan modus perlindungan dan motivasi serta disfemisme dengan modus penilaian negatif dan sindiran. Keempat modus tersebut secara leksikal dapat dicari tingkat perubahannya dengan membandingkan komponen makna setiap padanan katanya. Menguraikan bentuk perubahan eufemisme dan disfemisme tidak cukup dengan menggunakan latar belakang kalimat, jenis makna, dan kelas kata yang menjadi permakah. Ketiga konsep tersebut harus dilanjutkan pada tingkat komponensial dengan tujuan mencari tingkat perubahannya dalam setiap padanan kata dan setiap komponen maknanya.

\section{REFERENSI}

Amilia, F. \& Anggraeni, A.W. (2017). Semantik: Konsep dan Contoh Analisis. Malang: Madani.

Burridge, K., 2012. Euphemism and language change: the sixth and seventh ages. Lexis J. Engl. Lexicol. 7, 65-92.

Chaer, A. (2013). Pengantar Semantik Bahasa Indonesia. Jakarta: Rineka Cipta.

Chovanec, J. (2019). Euphemisms and non-proximal manipulation of discourse space: The case of blue-on-blue. Lingua: 225, 50-62.

Duffley, P. (2020). Linguistic Meaning Meets Linguistic Form. United Kingdom: Oxford University Press.

Eliya, I. (2017). Eufemisme dan Disfemisme dalam Catatan Najwa "Darah Muda Daerah": Pola, Bentuk, dan Makna. Dieksis, 22-30.

Fritz, I., Kita, S., Littlemore, J., \& Krott, A. (2021). Multimodal Language Processing: How Preceding Discourse Constrains Gesture Interpretation and Affects Gesture Integration When Gestures Do Not Synchronise with Semantic Affiliates. Journal of Memory and Language: 17, 1-17.

Heryana, N. (2019). Eufemisme dan Disfemisme Pada Media Berita Daring Republika: Perkembangan Kasus Setya Novanto Edisi Januari 2018. Jurnal Visi Ilmu Pendidikan, 62-76.

Jayanti, R., Maulida, N., Musdolifah. (2019). Eufemisme dan Disfemisme Pada Judul Berita Surat Kabar Harian Balikpapan Pos Periode April-Mei 2018. Basataka, 77-86. 
Khasan, A.M., Sumarwati., \& Setiawan, B. (2014). Pemakaian Disfemisme dalam Berita Utama Surat Kabar Joglo Semar. Basastra, 1-12.

Kurniawati, H. (2011). Eufemisme dan Disfemisme dalam Spiegel Online. Litera: 51-63.

Melcuk, I.A. (2012). Semantics from Meaning to Text. Amsterdam: John Benjamins Publishing.

Rabab'ah, G., \& Al-Qarni, A.M. (2012). Euphemism in Saudi Arabic and British English. Journal of Pragmatics: 44, 730-743.

Ritos, S., \& Daud, M.Z. (2020). Strategies for Replacing Dysphemism to Euphemism in Oral Communication of the Bidayuh, Bau Community: Pragmatics Analysis. Asian People Journal, 64-83.

Santosa, R. (2017). Metode Penelitian Kualitatif Kebahasaan. Surakarta: UNS Press.

Saputri, V., Ramadhan, S., \& Asri, Y. (2019). Eufemisme dan Disfemisme dalam Novel "Korupsi" Karya Pramoedya Ananta Toer. Retorika, 198-207.

Ullman, S. (2014). Pengantar Semantik. Yogyakarta: Pustaka Pelajar. 